\title{
The Possibility of Indonesia and United Kingdom to Form Free Trade Agreement After Brexit
}

\author{
Endah Ayu Ningsih \\ International Trade Cooperation \\ Policy Center \\ Ministry of Trade of Indonesia \\ Jakarta, Indonesia \\ ayuningsih.endah@gmail.com \\ Leo Mualdy Christoffel \\ International Trade Cooperation \\ Policy Center \\ Ministry of Trade of Indonesia \\ Jakarta, Indonesia \\ leo.christoffel@gmail.com
}

\author{
Fithra Faisal Hastiadi \\ Faculty of Economy and Business \\ University of Indonesia \\ Depok, Indonesia \\ fithra_faisal@yahoo.com
}

Fitri Tri Budiarti

International Trade Cooperation

Policy Center

Ministry of Trade of Indonesia

Jakarta, Indonesia

fitri.tribudiarti@kemendag.go.id

\author{
Risna Triandhari \\ Faculty of Economy and Business \\ University of Indonesia \\ Depok, Indonesia \\ risn419@gmail.com
}

\begin{abstract}
On June 23, 2016 held a referendum which resulted decision that United Kingdom or Britain determined to exit the European Union membership that we call Brexit. The exit of UK will absolutely impact UK's trade with its trading partner including Indonesia. In connection with this issue we conducted a study to evaluate the possibility for trade cooperation between Indonesia and the UK with assumption that UK had officially left the European Union. By having the Game Theory model, the best strategy for Indonesia is by forming FTA with UK. Meanwhile for UK, based on the simulation, the alternative in forming FTA with Indonesia is the dominant strategy with positive output. The trade cooperation implication is not too significant for UK, so to drive the trade cooperation must be initiated from Indonesia.
\end{abstract}

\section{Keywords-Brexit, Free Trade Agreement, CGE model}

\section{INTRODUCTION}

On 23 June 2016, the people of the United Kingdom (UK) voted to leave the European Union (EU). The vote resulted a referendum that Britain will exit the EU that we called Brexit. The UK government make sure that brexit will bring a successful and independent future for UK outside the EU (HM Government, 2017). The outcome of the UK's referendum on membership of the European Union (EU) will shape the future of the country's relationship with its largest trade partner - the EU -as well as other trade partner around the world. Some opinion suggests that EU membership has benefited UK economy since membership of the EU has reduced trade cost between UK and the rest of Europe (Harvey and Hubbard, 2016; Kierzenkowski et. al, 2016; Dhingra et. al, 2016). Thus, leaving the EU will give some losts to UK, one of the factors is the risks from uncertainty following the referendum (Steinberg, 2019).

A number studies analyze that Brexit possibly will increase as well as decrese welfare and trade with the European Union (Dhingra et al., 2016; Ebell et al., 2016; Baker et al., 2016). Some also argue that Brexit provide the opportunity for the UK to regain regulatory sovereignty and a relief from overly burdensome EU regulations (Booth et. al.,
2015; HM Government, 2017). This would be advantageous to the UK economy since UK has independence to negotiate new trade agreements with third countries (Busch and Metthes, 2016). However, the bargaining position to UK is relatively lower than if negotiating as a part of EU since the $\mathrm{UK}$ is only able to offer a smaller market than the EU.

The United Kingdom has been Indonesia's strategic partner. Diplomatic relation between the two countries has been managed for 70 years (Indonesia's State of Secretary, 2016). Trade value between both countries reached USD 2.6 billion in 2018, while investment from Britain in Indonesia reached more than USD 12 billion in the same year. United Kingdom is the $10^{\text {th }}$ biggest investor in Indonesia. The fact that United Kingdom leave EU will affect trade performance between them and also to the world. Moreover, it will shift UK's international trade policy with their partner, both main partner and potential partner. The form of the policy can be as maintaining EU as FTA trade partner and expanding bilateral trade cooperation with their potential trade partner. The research objective is to elaborate the potential bilateral cooperation between Indonesia and UK and how big the impact of having it, both for Indonesia and UK. This research will enrich researches focusing on International trade especially researches discuss economic integration also and use GTAP analysis as a tool analysing the impact of international trade cooperation.

\section{METHODOLOGY}

To assess the economic cost and benefit regarding the possibility trade agreement between Indonesia and UK after brexit, this study uses Game Theory and a Computable General Equilibrium (CGE) model with the employment of Global Trade Analysis Project (GTAP) Database (Version 9.0) and using GTAP standard model. GTAP database version 9 use three reference year (2004, 2007, and 2011) and we use the latest year (2011) as the reference year for this research.

The GTAP is CGE model that provide with multi-region and multi-sector with by default consist of 140 regions, 57 
commodities, and five productive factors for each region (Qi \& Zhang, 2017). We keep the commodities at 57 commodities and aggregate the regions into 10 regions from originally 140 regions, they are Indonesia, United Kingdom, Malaysia, China, India, Turkey, Egypt, European Union, African Countries and Rest of the world. Malaysia, China, India, Turkey, Egypt have been a potential trade partner for United Kingdom, so it's important to see the effect it could bring when they have trade cooperation agreement.

Will the UK consider to join FTA with Indonesia after Brexit, or is negotiating FTA with EU is the best choice for Indonesia? To answer this question, this study use Game Theory approach to presume what the best decision are taken both by UK and Indonesia.

Game theory is a study of mathematical models that describe the interaction between the two players and more who are rational individuals. It is is the logical analysis of situations of conflict and cooperation. Game theory could be formally defined as a theory of rational decision in conflict situations (Bhuiyan, 2016). There are interdependencies between player strategies. Each strategy will have different consequences for the player himself and other players. The most primitive solution concept to games does not require knowledge of the actions taken by the other players. A dominant strategy is the best choice for a player in a game regardless of what the others are doing (Valimaki, 2011).

The most primitive solution concept to games does not require knowledge of the actions taken by the other players. A dominant strategy is the best choice for a player in a game regardless of what the others are doing. Each person has a chance to better off his position by confessing. When the one confess, the other should consider to confess to avoid harsher sentence. When they all confess, the result is worse for both than when both keep silent. The next solution concepts assumes that rationality of the players is common knowledge. Common knowledge of rationality is essentially a recursive notion, so that every player is rational, every player knows that every player is rational, every player knows that every player knows that every player is rational, possibly ad infinitum. Finally, the Nash equilibrium concept requires that each player's choice be optimal given his belief about the other players' behavior, and that this belief be correct in equilibrium (Valimaki, 2011). Nash equilibrium is a fundamental concept in the theory of games and the most widely used method of predicting the outcome of a strategic interaction in the social sciences (Campbell and Miller, 2007).

We build four alternatives scenario regarding negotiation process between European Union and UK. The optimistic scenario assumes that in a post-brexit, the UK still enjoyed free tariff when trading with EU. This scenario is called DEAL scenario. In pessimistic scenario, this study assume that the UK is not successful in negotiating a new trade agreement with the EU, thus, the trade between UK and EU following brexit will respect World Trade Organization (WTO) rules. It means that EU will impose Most Favoured Nation (MFN) tariff to UK and vice versa. The pessimistic scenario is called NOT DEAL scenario.

DEAL scenario then is divided by two alternatives which are: First alternative, after brexit with free tariffs are still in affect between UK and EU, UK makes Free Trade
Agreement with any countries (the world except EU) including Indonesia. In the second alternative, with the same DEAL scenario, UK makes FTA with any countries (the world except EU) but excluding Indonesia. The same two alternatives then also applied in the NOT DEAL scenario. Therefor totally this study has four alternatives scenario regarding the trade agreement that probably undertaken by $\mathrm{UK}$ and Indonesia after Brexit

\section{RESULT AND DISCUSSION}

\section{A. Economic Relation Between Indonesia and UK}

Indonesia's total trade with the UK in 2017 reached 2.4 billion USD with downwarding trend during the 2013-2017 as amounted as $2.3 \%$ per year. The bilateral trade composition between Indonesia and the UK is dominated by non-oil and gas products. The export value in the same period has been fluctuated with the largest exports was recorded in 2014 amounting to USD 1.6 billion. This value declined in 2017 to USD 1.4 USD. In the 2013-2017 period, the average decline in exports per year was $3.3 \%$, while in terms of imports, the decline is relatively smaller at $0.6 \%$. This caused the trade balance to deteriorate during this period. The trade balance between Indonesia and the UK is given in Figure 1.

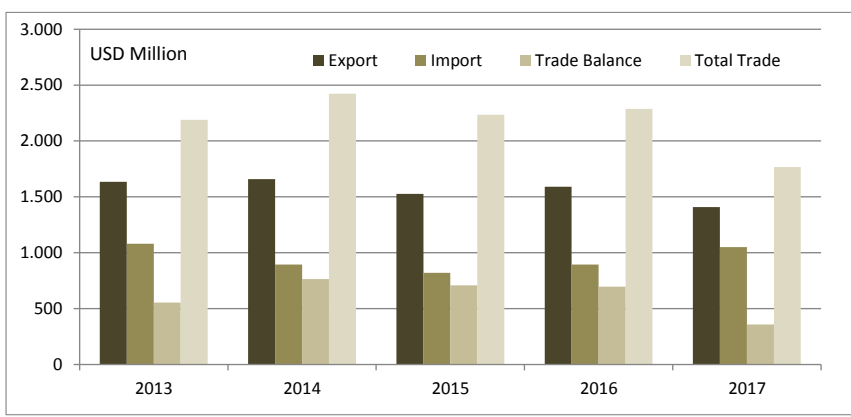

Fig. 1. Trade Performance Between Indonesia-UK 2013-2017

The basket of Indonesian exports to the UK consists of Indonesian traditional advantage products such as footwear with a share of $16.3 \%$ of Indonesia's total exports to the UK, wood and wood products $(9.7 \%)$, apparel $(7.7 \%)$, machinery and electrical equipment $(6.0 \%)$, furniture $(5 \%)$, paper $(5 \%)$ and other products. Meanwhile, Indonesia imports a lot of high technology products from the UK such as machines and its equipments with a share of $15.3 \%$ of Indonesia's total imports from the UK and electronic equipment for $14.2 \%$ of shares. Other imported products are aircraft $(7.1 \%)$, essential oils $(6.7 \%)$ and vehicles and spare parts $(6.2 \%)$.

Services trade between Indonesia and the UK has not been widely explored. According to UNCTAD records, the value of UK services exports to Indonesia in 2016 amounted to USD 553 million or merely $0.2 \%$ of total UK services exports globally. While the UK imports services from Indonesia is counted as USD 355 million or $0.2 \%$ of total of the UK imports from world. It's concuded that UK enjoy the surplus in terms of trade in services for amount of USD 198 million. The services sectors that are traded bilaterally between the two countries are travel and transportation which trade in these sectors are driven by tourism activities of both countries. The other services sector is government services.

In terms of investment, in 2017 UK was the 11th largest country to invest in Indonesia. The UK interests to invest in 
Indonesia in the variouse sectors such as food crops, plantations, food industry, mining, housing, industrial areas and offices, warehouse transportation and telecommunications (BKPM, 2019) . On the UK point of view, Indonesia is an attractive investment destination compared to other ASEAN countries. It is evident from the higher value of UK FDI stocks in Indonesia from Malaysia and Thailand in 2012.

\section{B. The UK's Challenges in Brexit Negotiation}

Although the UK and the EU have expressed their desire to achieve mutually satisfying results and negotiate with good intentions, the negotiation process remains full of difficulties and challenges due to the complexity that arises from Britain's exit (Ian, 2016). The Brexit process will involve renegotiating 759 agreements with third countries (McClean, 2017). There are two phases in the negotiation process that need to be resolved. The first phase will focus on three main issues that form the basis of the Brexit agreement, namely EU citizens' rights in the UK and vice versa, the Irish border, and Britain's financial obligations towards the EU as a consequence of Brexit (Wright N., 2017). The agreement reached between the UK and EU Chief Negotiator Michel Barnier has paved the way for the second phase of relations between the UK and EU after Brexit (European Commission, 2017).

However, the process of going to that stage still has many challenges due to a variety of sensitive issues covering these three main issues. In the early stages, Britain's financial obligations towards the EU appeared to be one of the tough challenges until finally the United Kingdom agreed to pay $€$ 50 billion to the EU as part of the agreement to issue Britain (Rettman, 2017). In addition, issues related to the Irish border are also a serious challenge for the development of negotiations, especially on the side of economic impact because around $80 \%$ of Irish land transportation must go through the UK (Posaner \& Livingstone, 2017). In overcoming this, the United Kingdom promised to make the border smooth and without obstacles as much as possible (HM Government, 2017). However, on the other hand the United Kingdom promised to withdraw from the EU Single Market and Customs Union system (Posaner \& Livingstone, 2017). Furthermore, the UK is also faced with the potential impact that will affect the Belfast (Good Friday Agreement) and vulnerable political conditions in Northern Ireland (Leahy \& Minihan, 2017).

In addition, the Brexit negotiation process is also faced with the possibility of no agreement between the UK and the EU, or referred to as the 'No Deal' scenario (Ross \& RossThomas, 2017). This will make relations with key UK partners in Europe increasingly difficult because of the uncertainty of Britain's legal position in trade partner relations with the EU (House of Commons Foreign Affairs Committee, 2017). Then, this condition will also influence the reputation and credibility of the UK in the international eye (Usherwood, 2017). In addition to mitigating various possible risks, the UK's foreign policy makers in the Foreign and Commonwealth Office (FCO) are also hampered by the domestic context because negotiations are managed and carried out by the Department for Exiting the European Union (DExEU) and the coordination process carried out by the UK government in facing all possibilities (House of Commons Foreign Affairs Committee, 2017).

\section{Economic Potential Effect from Trade Cooperation}

This research uses CGE simulation to measure the possible effect that might occur if Indonesia and United Kingdom raise bilateral trade cooperation by liberating their import tariff. The simulation is limited to trade in goods with cross-border mechanism by eliminating all tariff from tradeable products. The macro economy variables used in the simulation are welfare, trade balance, industry output, service output, and total economic change represent by PDB change for each country. Those macro indicators are counted as aggregate effect nationally not bilaterally. For instances, the change of trade balance explained in figure 2 is total trade balance for each country as a result of cooperation formed between Indonesia and United Kingdom.

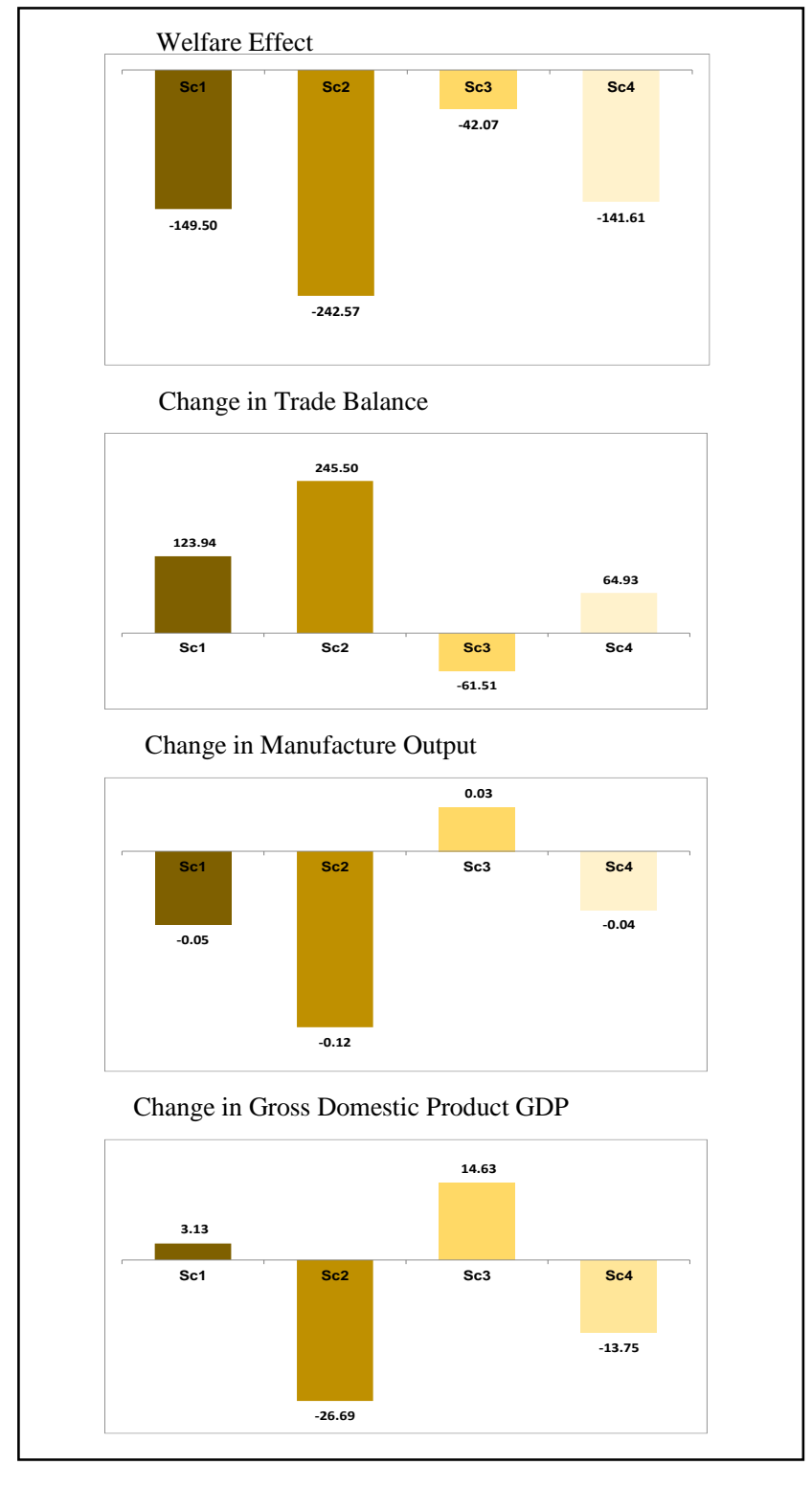

Source: GTAP Simulation

Fig. 2. GTAP Simulation Results to Indonesian Economy

Figure 2 gather results from CGE simulation capturing Indonesian economy which executed using GTAP version 9. Label Sc1 refers to DEAL Scenario alternative 1 (DEAL and UK forming FTA with Indonesia), Sc2 refers to DEAL Scenario alternative 2 (DEAL and UK not forming FTA with 
Indonesia), Sc3 refers to DEAL scenario alternative 3 (NOT DEAL and UK forming FTA with Indonesia), and Sc4 refers to DEAL scenario alternative 4 (NOT DEAL and UK not forming FTA with Indonesia).

In DEAL scenario, If Indonesia forming FTA with UK, Indonesia will experience GDP increment about USD 3.13 million, an increase of USD 123.9 million of trade balance. The welfare will suffer as much as USD 149.5 million and industry output will reduce for about USD 50 thousand. But when Indonesia not forming FTA with UK, Indonesia will risk for the downfall of GDP for USD 26.7 million, welfare and industry output will suffer more in this scenario. But, Indonesia will gain trade surplus reaching USD 245.5 million.

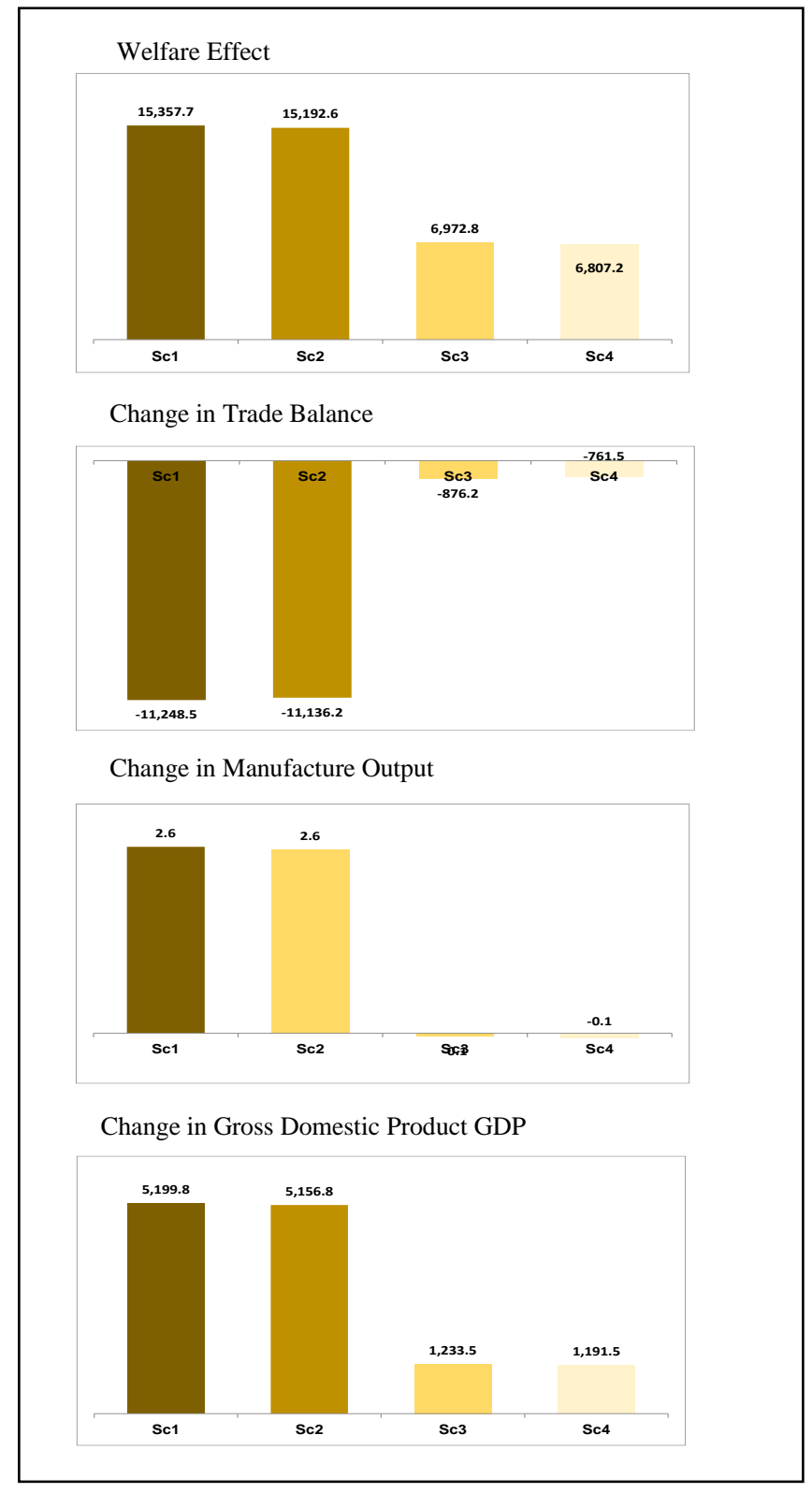

Source: GTAP Simulation

Fig. 3. GTAP Simulation Results to UK Economy

Furthermore, in NOT DEAL scenario, if UK forming FTA with their trade partners, including Indonesia, Indonesia will gain GDP increase as much as USD 14.6 million. But Indonesia trade balance will suffer for USD 61.5 million, welfare will reduce for USD 42.1 million and Indonesia will experience output increment for about USD 30 thousand. In NOT DEAL scenario, if UK not forming FTA with Indonesia, then Indonesia will be suffer from it because there will be a bigger trade diversion compared with if UK forming FTA with Indonesia

Figure 3 shows the simulation result for UK economy. In all simulation scenario, UK will have welfare increment as an effect of trade cooperation (FTA). In contrast, Indonesia's welfare will suffer from it. In DEAL scenario, UK will have the worst effect related to their trade balance, but for industry output and PDB increase, UK will experience a bigger benefit rather than in NOT DEAL scenario. By looking at figure 3, scenario DEAL definitely will give UK benefit.

By seeing through both scenarios, any alternatives that UK made, by forming trade cooperation with all their trade partners including Indonesia, will take UK to have better economic implication. Forming trade cooperation Indonesia, will give slight differences for each UK's macroeconomic indicators. It happens because the limited trade practices with Indonesia made the economic implication after trade cooperation is formed become less significant for UK.

\section{Best Alternative}

The simulation result from fourth scenario give implications to each country. In fact, each country will decide the best alternative from all alternatives. This research use game theory approach to predict dominant strategy of alternative that might be chosen by each country. Assumption used is the decision that each country made using prisoner dilemma assumption. The players in prisoner dilemma are Indonesia and UK. Two pay off matrix will be use having two scenario in each, they are DEAL and NOT DEAL. The game alternative for DEAL scenario is simulation $\mathrm{Sc} 1$ and $\mathrm{Sc} 2$. The game alternative for NOT DEAL scenario is simulation $\mathrm{Sc} 3$ and $\mathrm{Sc} 4$. Pay off function used in thie game are PDB change resulted from GTAP version 9 .

TABLE I. PAY OFF MATRIX FROM SCENARIO DEAL

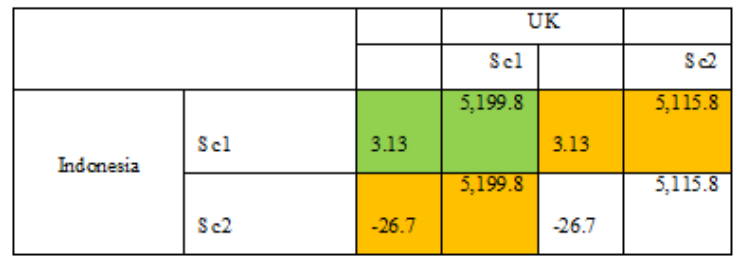

Based on Table I, the dominant strategy to Indonesia in DEAL scenario is forming trade cooperation with UK. Meanwhile for UK, the dominant strategy is forming trade cooperation with Indonesia.

TABLE II. PAY OFF MATRIX FROM SCENARIO NOT DEAL

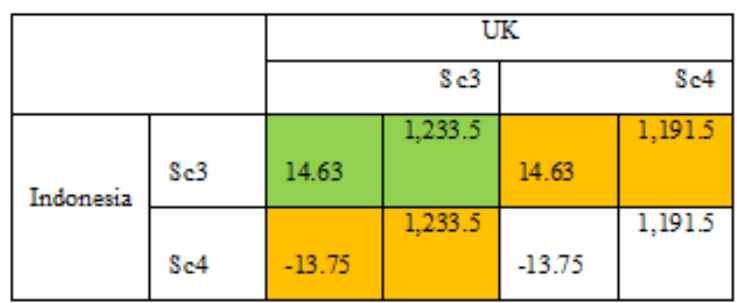


Based on Table II, the dominant strategy to Indonesia in NOT DEAL scenario is forming trade cooperation with UK. Meanwhile for UK, the dominant strategy is also forming trade cooperation with Indonesia. Moreover, Game Theory approach conclude that in any scenario, the dominant strategy for both countries is forming trade cooperation.

\section{CONSLUSION AND POLICY IMPLICATION}

The research concluded that trade cooperation leverage after Brexit with UK is feasible and will give benefits to Indonesia compared to if Indonesia not forming trade cooperation with UK. GTAP simulation resulting that In DEAL scenario, If Indonesia forming FTA with UK, Indonesia will experience Gross Domestic Product (GDP) increment about USD 3.13 million, an increase of USD 123.9 million of trade balance. The welfare will suffer as much as USD 149.5 million and industry output will reduce for about USD 50 thousand. For UK, any alternatives that UK made, by forming trade cooperation with all their trade partners including Indonesia, will take UK to have better economic implication. Having the game theory model, the best strategy for Indonesia is by forming FTA with UK. Meanwhile for UK, based on the simulation, the alternative in forming FTA with Indonesia is the dominant strategy with positive output. The trade cooperation implication is not too significant for UK, so to drive the trade cooperation must be initiated from Indonesia. EU tend to formed trade cooperation with their partners with Economic Partnership scheme, so it might be adopted by UK when they forming trade cooperation with Indonesia. EU tend to formed trade cooperation with their partners with Economic Partnership scheme, so it might be adopted by UK when they forming trade cooperation with Indonesia.

\section{ACKNOWLEDGMENT}

This paper is made based on research conducted by the Centre of Research of International Trade Cooperation in 2018 budget year. The author would like to thank to all fellows involved for giving their best contribution in this research

\section{REFERENCES}

[1] Baker, Jessica, Oriol Carreras, Simon Kirby, Jack Meaning, and Rebecca Piggott, "Modelling events: The short-term economic impact of leaving the EU," Economic Modelling, 2016, 58 (C), 339 350

[2] Bhuiyan, B, A. (2016). An Overview of Game Theory and Some Applications. Philosophy and Progress. Bangladesh: University of Dhaka.

[3] Booth, Stephen, Howarth, C., Persson, M., Ruarel, R., Swidlicki, P. 2015. What if..? The Consequences, Challenges and Opportunities Facing Britain Outside EU. Report 03/2015. London: Open Europe.

[4] Busch, B and Matthes, J.(2016). Brexit - the economic impact: A meta-analysis. German: German Economic Institute.

[5] Campbell, W, K \& Miller, J, D. (2007). International Encyclopedia of The Social Sciences, 2nd Edition. 540.

[6] Dhingra, Swati, Gianmarco Ottaviano, Thomas Sampson, and John van Reenen, "The Impact of Brexit on Foreign Investment in the UK," CEP Brexit Analysis 3, Centre for Economic Performance 2016.

[7] Ebell, Monique, Ian Hurst, and James Warren, "Modelling the longrun economic impact of leaving the European Union," Economic Modelling, 2016, 59, $196-209$.
[8] European Commission. (2017, Desember 8). Communication from the Commission to the European Council (Article 50). Brussels. Taken from https://ec.europa.eu/commission/sites/betapolitical/

[9] Harvey, D and Hubbard, C. (2016). Why Brexit?. Centre for Rural Economy Discussion Paper Series No. 35

[10] HM Government. (2017, Februari 2). The United Kingdom's exit from and new partnership with the European Union. Taken from United Kingdom Government:https://www.gov.uk/government/publications/theunited-kingdoms-exit-from-and-new-partnership-with-the-europeanunion-white-paper

[11] House of Commons Foreign Affairs Committee. (2017). Article 50 negotiations: Implications of 'no deal', Ninth Report of Session 2016-17. London: House of Commons of the United Kingdom.

[12] Ian, D. (2016). Brexit: What the Hell Happens Now?: Everything You Need to Know about Britain's Divorce from Europe. Kingston upon Thames: Canbury Press.

[13] Indonesia Investment Coordination Board. (2016). Post Brexit : A Prospect for UK's Investment Expansion to Indonesa. Jakarta: BKPM.House of Commons Foreign Affairs Committee. (2017). The FCO and The 2015 Spending Review. London: The Stationery Office.

[14] Indonesia Investment Coordinating Board.(2019). Jakarta: https://nswi.bkpm.go.id/data_statitstik.

[15] Indonesia's State of Secretary. 2019. Brexit Won't Affect IndonesiaUK Relations, Foreign Minister Says. Cited on https://setkab.go.id/en/brexit-wont-affect-indonesia-uk-relationsforeign-minister-says/?yop_poll_tr_id=\&yop-poll-nonce1_yp586111c417d39=0897af2316. Retrieved on 23 August 2019.

[16] Kierzenkowski, R., N. Pain, E. Rusticelli, and S. Zwart, 2016. "The economic consequences of Brexit: A taxing decision," OECD Economic Policy Papers 16, OECD Publishing.

[17] Leahy, P., \& Minihan, M. (2017, Juli 29). Varadkar's comments on Brexit are a sharp message to London. Taken from The Irish Times:https://www.irishtimes.com/news/politics/varadkarscomments-on-brexit-are-a-sharp-message-to-london-1.3170367

[18] McClean, P. (2017, Mei 30). After Brexit: the UK will need to renegotiate at least 759 treaties. Diambil kembali dari Financial Times: https://www.ft.com/content/f1435a8e-372b-11e7-bce49023f8c0fd2e?mhq5j=e2

[19] Posaner, J., \& Livingstone, E. (2017, Juli 20). Brexit burnsIreland's British bridge to EU markets. Taken from Politico: https://www.politico.eu/article/cargo-food production-producersbrexit-burns-irelands-british bridge-to-eu-markets/

[20] Qi, C and Zhang, J, X. (2017). The economic impacts of the ChinaAustralia Free Trade Agreement - A general equilibrium analysis

Newcastle Business School, University of Newcastle.Australia: China Economic Review, 2017.

[21] Rettman, A. (2017, November 29). Reports: UK agrees to pay €50bn Brexit bill. Taken from euobserver:https://euobserver.com/ukreferendum/140073

[22] Ross, T., \& Ross-Thomas, E. (2017, Oktober 3). Davis Says the U.K. Is Making Contingency Plans for a No-Deal Brexit. Taken from Bloomberg: https://www.bloomberg.com/news/articles/2017-1003/davis-says-u-k-is-making-contingency-plans-for-no-deal-brexit

[23] Steinber, J.B.(2019). Brexit and the Macroeconomic Impact of Trade Policy Uncertainty. Canada: University of Toronto, Department of Economics.

[24] Usherwood, S. (2017). The political and reputational costs of 'no deal'. Taken from the Department of Politics at the University of Surrey: http://blogs.surrey.ac.uk/politics/2017/07/20/political-andreputational-costs-of-no-deal/41/

[25] Valimaki, J. (2011). Microeconomic Theory: Basic Game Theory. Department of Economics. University of Yale.

[26] Wright, N. (2017). Brexit \& The Re-Making of British Foreign Policy. UCL European Institute Working Paper. 